\title{
Safety Assessment of Persons And Property at The Bus Station
}

\section{MARTA BLAHOVÁ \& BARBORA KOTKOVÁ}

Abstract: This paper deals with the explanation of the general concept in relation to the topic, hereafter defines particular types of protection of persons and property, that it could find on the bus station, and specifies the competent security forces and their competences. The safety assessment at the bus station follows and the possible involved risks are analyzed. According to the results of the investigation, measures have been suggested in aim to decrease the risks.

Key words: Bus, Persons, Property, Protection, Risks, Security, Station
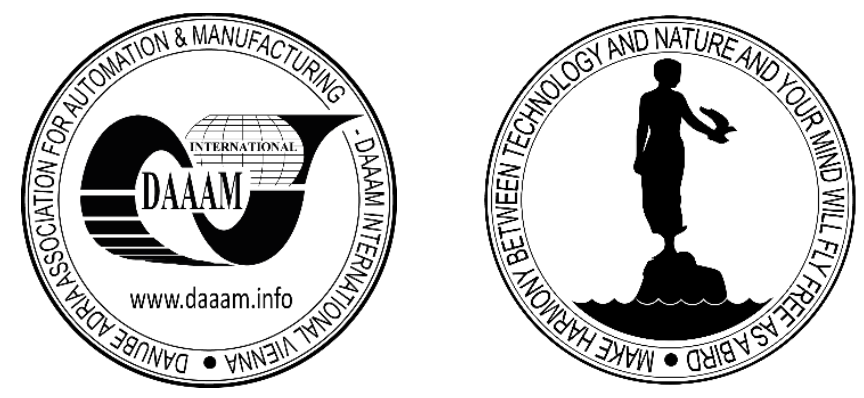

Authors' data: Blahova, M[arta] \& Kotkova, B[arbora] Fakulta aplikované informatiky - Univerzita Tomáše Bati ve Zlíně, Nad Stráněmi 4511, 76005 Zlín, CZ, m6_blahova@utb.cz,b_kotkova@utb.cz

This Publication has to be referred as: Blahova, M[arta] \& Kotkova, B[arbora] (2019). Safety Assessment of Persons and Property at the Bus Station, Chapter 26 in DAAAM International Scientific Book 2019, pp.313-320, B. Katalinic (Ed.), Published by DAAAM International, ISBN 978-3-902734-24-2, ISSN 1726-9687, Vienna, Austria

DOI: $10.2507 /$ daaam.scibook.2019.26 


\section{Introduction}

Security is an important part of everyday life. It is necessary to pay increased attention to it. The security situation of all objects with a high concentration of people is constantly worsening. A huge number of people move daily at the bus station. There are significant deficiencies in measures here. A safety analysis is therefore necessary. On the basis of the results there have to be taken new measures or improved the old ones. The elements involved in ensuring safety are also important.

For all buildings facing potential hazards, the current safety status must first be assessed. The risks that may be present here must be identified. These must be described and analyzed. Finally, based on the results of this analysis, measures can be proposed.

\section{Security of Persons and Property}

The security situation of the Czech Republic within Europe is so far without serious security problem. However, this situation can change at any time, especially as a result of our country's increasing involvement in NATO and the EU. Our dependency is increasing because of the common and effective action of the international community against sources of threat and the resolution of possible emergencies or crises.

Terrorism is one of the risks currently being addressed worldwide. In the Czech Republic such cases are not yet known, but in the world such attacks have occurred.

Some of the known attacks on the bus station are attacks [1]:

- Israel, March 2011, bomb attack at a bus stop near Jerusalem Bus Station [2]

- Nigeria, March 2013, suicide attack near Kano bus station [3]

- Ukraine, February 2015, shelling in the city of Donetsk, which also affected the car-bus station [4].

It is in the interest of the state to take precautionary measures to make people feel safe, especially in public places. Just as people have learned to predict the pitfalls of the elements, felony and criminal phenomena can be predicted to some extent, and preventive measures can be taken to some extent, thanks to advances in technical, informational, legal, criminology, criminalistics and other fields, that constantly improve the protection of persons and property [5].

\section{Protection of Persons and Property in Czech Republic}

People always needed to protect themselves, others, property and other values. Only the ways and means of protection have changed over time. It is influenced by the lifestyle and conditions of people's lives. 
Protection is a passive way to avert or reduce danger. The beginning is in prevention. Through available methods, means and organizational measures, we will impede or prevent attacks against a protected interest. In some cases, at least we minimize their consequences. Effective protection can be achieved by combining elements of a complete alarm system. These include: physical protection, classical protection, mode protection and technical protection. The interconnection of these elements creates an integrated safety system.

The basic components in the Czech Republic, such as the Fire Rescue Service of the Czech Republic, fire brigade units, rescue service providers and the Czech Police, are involved in ensuring the safety of persons and property. [6].

The task of these units is to define the risk areas where a large number of people gather and ensure their safety situation is improved. Mutual coordination of components contributes to increasing the security of citizens. Their task is to provide in particular, preventive protection of the safety of persons and property.

The Czech Police is a uniform armed security force of the Czech Republic serving the public. Their priority is to protect the safety of persons and property, public order and prevent crime, in addition to performing tasks under the Criminal Procedure Code and other tasks in the field of internal order and security entrusted to it by the laws, regulations of the European Communities and international treaties [7].

The aim of the Police of the Czech Republic is to protect security and order in society, to promote the rule of law, to protect the rights and freedoms of persons, to prevent and combat crime and other illegal activities, to seek lasting support and public confidence [7]. The Municipal Police have the task is to secure public order matters within the competence of the municipality or several municipalities on the basis of the law. It cooperates to the extent stipulated by law or a special legal regulation with the Police of the Czech Republic, state authorities and bodies of territorial self-governing units [8].

The security service itself uses very few soft targets. At the same time, the mere presence of security personnel does not guarantee the fulfillment of the necessary security tasks. However, some regime measures do not require special knowledge or skills and may be carried out by any instructed, if not professional, staff. All employees should be instructed in the following areas:

- what are the specific risks on the facility,

- how to identify a suspicious item, vehicle, person or shipment,

- how to act in the event of an attack or other serious incident.

The main advantage of the local staff is their knowledge of the local environment. This makes it easier than for anyone else to detect people or objects that are out of routine and might be dangerous. The ability to detect suspicious persons or objects is a weak point of the single time involved security professionals, who have knowledge of procedures, but at the same time they face a great obstacle to understand the unknown environment.

Due to their presence at the scene of the incident, unprofessional staff will usually be the first to report any emerging danger or security incident. Nevertheless, it is advisable to instill at least the first reaction, the basic direction to be taken in a security incident, to lay personnel. [9] 


\section{Safety of Bus Station}

The bus station is a public space with various groups of people. It provides regular urban, intercity and international public transport.

The station usually includes:

- the building of the bus station, where the waiting room, information and office, buffet, sanitary facilities and also offices of individual managers department,

- stops with boarding islands,

- roads including roundabouts, sidewalks, crossings.

The bus station, like other public spaces, has to cope with the high movement of people of different social status, age and gender, who are transiting and waiting for connections, or are waiting for someone else or staying there for other reasons.

The large concentration of people attracts the attention of pocket thieves and crowd anonymity is an opportunity for street vendors and fraudsters. Property crime, consisting mainly of petty theft, has been decreasing in recent years. It is possible that people are more cautious about personal things. Drug issues are currently avoiding the bus station, and any identified cases do not jeopardize the safety of people and property here at the bus station.

Unfortunately, today's security situation forces us to prepare for a possible terrorist act. Bus station buildings are largely obsolete and do not take into account this risk. At the time of their construction it was not necessary to count on this possibility. It is therefore necessary to take the necessary precautions in these places, corresponding to the new security situation.

\section{Safety Analysis}

Safety analysis can be performed using two methods. The first well-arranged method is the Ishikawa diagram. It will illustrate the individual risks that lead to safety threats at the bus station. As a second method we can use SWOT analysis, which analyzes the current safety status of the bus station, its strengths and weaknesses, opportunities and threats. Based on the threats resulting from the analysis, measures can be proposed to eliminate them.

The safety of persons at the bus station is endangered in various ways. What is important for the state is that there are many soft targets. This severely limits the practical possibilities of their securing only by the state, resp. and increases the importance of the security measures taken by the soft targets themselves. In additional, a number of soft targets can better secure their security (eg it has more resources knowledge of the environment, contact with it, the presence of people on the spot, but also funds, etc.) than the state. [9]

The causes are aggression of a person or organized groups of people, theft, traffic offense, carelessness of persons. This can result in serious injury, material or financial damage. Risk analysis through the Ishikawa diagram (also known as herringbone or cause-and-effect diagram) can show the causes that lead to the effect. 
It is then necessary to carry out a risk analysis and propose new measures to minimize security risks. If there are no major discrepancies between the existing measures and the new ones, the current ones can only be improved.

The most common risks:

- theft, in which people may be deprived of their belongings, either in the station building while waiting, moving around the bus station, or while waiting at a station island;

- vandalism, where the property of the bus station is mainly damaged. Buses, timetable signs, waste bins, glass panels, etc. may be damaged;

- attacking people or an organized group of people who are under the influence of alcohol or other addictive substances or who are aggressive because of a mental disorder. In the event of an attack, persons may be endangered for health or life without reason;

- a fire that may result in the ejection of cigarette butts, the handling of awaiting fire in a station building, an accident or a technical defect that results in leakage of fuel or other substances and subsequent ignition. It is also not possible to exclude fire by lightning strikes or deliberate ignition;

- terrorist acts committed by an individual or organized group of persons for religious, political, racial or other reasons;

- other circumstances, if any.

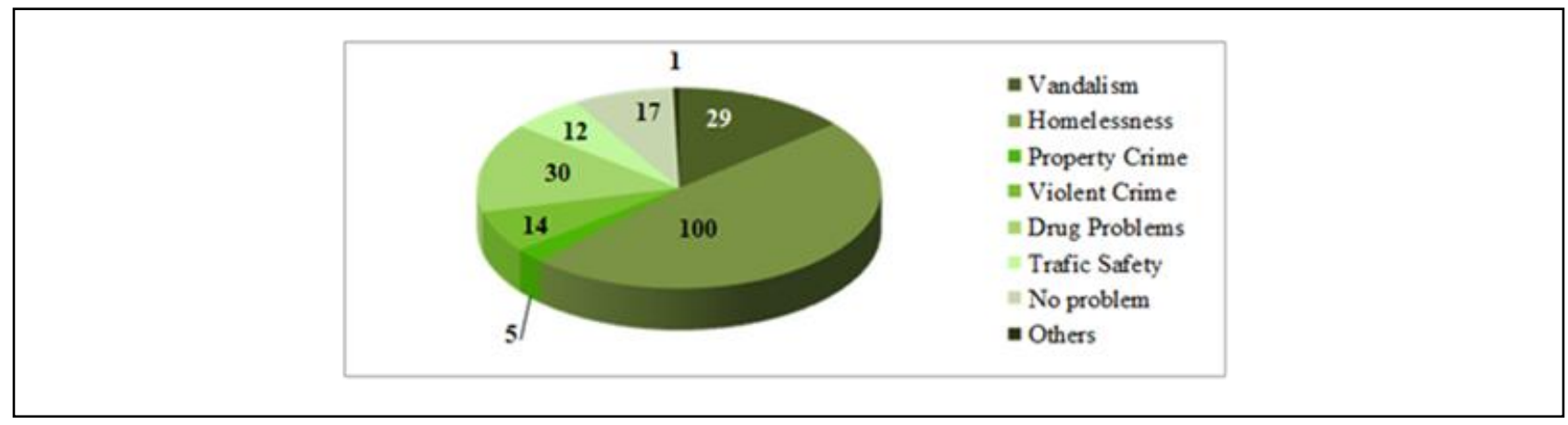

Fig. 1. Offenses at the bus station [1]

To evaluate the current safety status of the bus station, a SWOT analysis can be used to analyze the strengths, weaknesses, opportunities and threats of the bus station. The strongest point in most of these objects is always the cooperation of security forces. The most frequently identified risk factor threatening the safety of persons and property at the bus station is then outdated solutions not using today's modern security equipment. These should be the starting point for the elaboration of a new draft of measures to eliminate newly found risks arising from the current global situation.

Based on the results of the analyzes, it follows (e.g. safety analyzes of cities and regions) that the safety of persons and property at bus stations is endangered by certain risks. These risks cannot be neglected and measures need to be devised to mitigate these risks. This will increase the safety of bus stations. 
When assessing the safety of persons and property at the bus station by SWOT analysis, we find that the most serious danger is the occurrence of fire. Another threat is assault, theft and vandalism. Terrorist acts in the Czech Republic remain the least likely scenario, but with the most serious consequences, and therefore this risk must not be omitted.

\section{Risk reduction prevention measures}

Prevention is an important factor in the fight against crime, therefore all measures must be based on greater awareness of persons, municipalities and states. This information may be transmitted by police officers, school educators or other groups dealing with citizens' information programs. The necessary information can be given to citizens by setting up town websites, local TV broadcasts, local radio, local press, city information boards or posters and leaflets located at the bus station. Prevention programs must also target seniors, pupils or students. They must give a lecture on security and risks in public areas, how to behave if they become witnesses or victims of illegal acts. Security will increase even more frequent walking activity of police officers during day and night time.

\section{Eliminate the risk of fire at the bus station}

The risk of fire in the bus station building is very likely to endanger the safety of persons and property. The fire may be caused intentionally, by the negligence of the passengers or their own employees. Another possibility is a defect in the facilities located in the building and a possible bus accident near the building. This will cause fuel leakage and rapid fire spread. The aggravating circumstance may be the wind speed. There is also a risk of lightning, especially in old buildings with a broken or damaged lightning conductor. Since it is obvious that there are many reasons for a fire, it is necessary to provide for this risk. EPS measures and fire extinguishers can be effectively used to eliminate this risk. Fire extinguishers must be located in the building in sufficient quantity in proportion to the building dimensions. Their number and location must be determined by a specialist. EPS must also be implemented or multisensor EPS detectors can be installed. EPS smoke detectors should be installed in all offices, corridors, floors, staircases and waiting rooms. The multi-sensor EPS detectors must be connected to the control panel and the central security desk.

\section{Eliminate the risk of terrorism, vandalism and theft at the bus station}

Vandalism and theft at the bus station are common and therefore cannot be neglected. There should be prevented damages to the functionality of buildings, escape exits, and safety devices. These urgent repairs carry high financial costs. Therefore, it is preferable to take measures that reduce the likelihood of these threats occurring.

Bus station buildings must be secured against the intrusion of foreign persons, which can cause injury or death during operation. 
Also against burglary when the building is out of service, when it is possible to prepare a terrorist act or an event endangering the health and lives of people. The solution is to place motion sensors with alarm connected to the control panel in each room, including corridors and all entrances, and this device is connected to the monitoring service monitoring center.

In order to improve the security system, it is possible to set up a modern camera system covering the entire area of the bus station. This will not only document activity at individual sites, but also around buildings and waiting rooms. Place outdoor cameras in the platform area and indoor cameras in the buildings. These measures would generally cover the bus station and its surroundings with a camera system, thus ensuring monitoring of the area.

This would reduce the opportunities for offenses and crime. If committed, the system would contribute to their easier detection and also as evidence. At the largest bus stations, especially in buildings, it is advisable to install safety frames or face recognition cameras in the busiest transport terminals. A private security service that would provide physical security would also benefit.

\section{Conclusion}

The highest efficiency in safety can always be achieved by combining all possible measures. It is therefore necessary to pay attention to prevention, technical measures, but also sufficient anchoring in the legislation. The current security system of bus stations in the Czech Republic is at a good level. However, there are shortcomings that need to be addressed. It is necessary to add in advance measures to prevent actions arising from the global situation, in particular, violent crime, organized crime and terrorist attacks. Unfortunately, there is a growing threat of political, religious, racial or other intolerance. Places with a high concentration of people are selected to attract the attention of the mass media and cause the greatest possible health and life threats. Technology needs to be installed to deter a potential attacker or mitigate the consequences of a terrorist attack.

The most thorough security measures in land transport were introduced by Spain after a serial bomb attack on suburban trains in 2004. Passengers on high-speed trains must pass through metal detectors detecting weapons and metal parts of explosive devices.

In the Czech Republic, almost no transport terminal is currently better secured against a terrorist attack than a regular supermarket. To date, security at public transport terminals has not been addressed by any specific measures, but only by routine rules. An example is the Prague Central Station, which has recently been upgraded, but the level of security systems has not significantly increased. [10]

The aim to be achieved is to strengthen the security system and increase the safety of both persons and property. 
Blahova, M. \& Kotkova, B.: Safety Assessment of Persons and Property at the Bus ...

\section{References}

Fiantová, A. (2015). Assessing the Safety of Persons and Property at the Bus Station in Uherske Hradiste.

A bomb attack in Jerusalem injured 31 people. Week: Terrorism. (2011). Available from:http://www.tyden.cz/rubriky/zahranici/asie-a-oceanie/pumovy-utok-vjeruzaleme-zranil-31- lidi_197192.html\# .

The attack on the bus station in Nigeria claimed 41 dead. (2013). Available from: http://www.denik.cz/ze_sveta/utok-na-autobusove-nadrazi-v-nigerii-si-vyzadal-41mrtvych- 20130319.html

he shelling of a bus stop in Donetsk claimed four dead. (2015). Available from: http://www.novinky.z/zahranicni/evropa/361340-ostrelovani-autobusove-zastavky-vdonecku-si-vyzadalo- ctyri-mrtve.html

Kameník, J. \& Brabec, F.(2007) Commercial security: private security activities of detective agencies and security agencies. Praha: ASPI, ISBN 978-80-7357-309-6.

[6] Czech Republic. (2000). On the Integrated Rescue System and on the Amendment of Some. Acts. In: Collection of laws of the Czech Republic. 2000. Available from: http://www.zakonyprolidi.cz/cs/2000-239 Vokuš, J. (2010). Police of the Czech Republic: Police of the Czech Republic: help and protect. ISBN 978-80-254- 7701-4. Available from: http://www.policie.cz/clanek/o-nas-policie-ceske-republiky-policieceske-republiky.aspx Czech Republic. (1991) On municipal police. In: Collection of Czech Laws Republic. Available from: http://www.zakonyprolidi.cz/cs/1991-553

Ministerstvo vnitra České republiky. (2019). https://www.mvcr.cz/clanek/ochranamekkych-cilu.aspx

Prochazkova, D.; Prochazka, J.; Rusko, M.; Mikulova, M. \& Ilko,J. (2017). Model for Critical Infrastructure Safety Management, Proceedings of the 28th DAAAM International Symposium, pp.0602-0610, B. Katalinic (Ed.), Published by DAAAM International, ISBN 978-3-902734-11-2, ISSN 1726-9679, Vienna, Austria 